\title{
Vad hände med 1990-talets stora förlorargrupper? Välfärd och ofärd under 2000-talet
}

JOHAN FRITZELL, MICHAEL GÄHLER \& MAGNUS NERMO

Kommittén Välfärdsbokslut pekade ut tre grupper som speciellt missgynnades av 1990-talets kris: ensamstående mödrar, invandrare och ungdomar. I denna artikel studerar vi hur välfärden utvecklats för dessa grupper under

2000-talets första fem år. Vi fokuserar på tre centrala välfärdsdimensioner: arbetsmarknad, ekonomi och hälsa. Resultaten pekar bland annat på en polarisering av välfärden inom dessa grupper.

\section{Inledning}

Få samhällsvetare kunde förutse vidden av den ekonomiska kris som drabbade landet under 1990-talets inledande år. Som beskrivs i inledningen till detta temanummer minskade Sveriges bruttonationalpro-

Johan Fritzell, professor i sociologi, Centrum för forskning om ojämlikhet i hälsa (CHESS), Stockholms universitet/Karolinska institutet \& Institutet för framtidsstudier, Stockholm.

Michael Gähler, docent i sociologi, Institutet för social forskning (SOFI), Stockholms universitet. Magnus Nermo, fil.dr. i sociologi, Institutet för social forskning (SOFI), Stockholms universitet. dukt tre år i rad och på mycket kort tid försvann mer än en halv miljon jobb (netto). Dessa dramatiska förändringar, liksom de påföljande nedskärningarna i de offentliga utgifterna och skattehöjningarna, hade naturligtvis en stor inverkan på människors välfärd och vardagsliv. Ett kännetecken för 1990-talets ekonomiska kris var dess vittgående omfattning. Till skillnad mot tidigare svåra kriser i början av sjuttio- och åttiotalen blev arbetslöshet och ekonomiska svårigheter mer kännbara för befolkningen i stort. Trots detta slog inte krisen blint. I Kommittén Välfärdsboksluts slutbetänkande (SOU 2001:79) och i en rad av dess 
forskarantologier underströks att ungdomar, invandrare och ensamstående mödrar erfor en speciellt negativ välfärdsutveckling under krisåren på nittiotalet. Tre dimensioner av välfärden, arbetsmarknadsförankring, ekonomiska resurser och hälsa, stod i fokus. Nedgången i sysselsättningen kom att slå särskilt hårt mot ungdomar och (nyanlända) invandrare. Försämringar i ekonomiska resurser drabbade framförallt ensamstående mödrar medan försämringar av i synnerhet unga människors psykiska hälsa väckte oro när det gällde befolkningens hälsotillstånd.

Vad hände sedan? Syftet här är att studera välfärdsutvecklingen sedan slutet av 1990-talet för unga, utrikesfödda och ensamstående mödrar i termer av arbete, ekonomi och hälsa. Detta sker i ljuset av de relativt goda ekonomiska förhållanden som rått $i$ landet under senare år. Den övergripande frågan är: hur har dessa tre gruppers levnadsvillkor utvecklats sedan 1990talets slut? Har ungas, utrikesföddas och ensamstående mödrars levnadsförhållanden närmat sig befolkningen i stort eller har dessa grupper fortsatt att halka efter?

\section{Varför drabbades unga, utrikesfödda och ensamstående mödrar särskilt hårt av 1990-talets kris?}

Det finns flera, delvis överlappande, skäl till att välfärdsutvecklingen under 1990-talskrisen kom att bli särskilt negativ för unga, utrikesfödda och ensamstående mödrar. En orsak till detta är att alla tre grupper, $\mathrm{i}$ all sin heterogenitet, är särskilt sårbara för försämrade konjunkturer på arbetsmarknaden. Ungdomar på grund av arbetsrättsregler ("sist in först ut") och för att de i hög utsträckning saknar arbetslivserfarenhet, utrikesfödda för att de ofta har relativt lite arbetslivserfarenhet i Sverige och ensamstående mödrar för att de är ensamma familjeförsörjare. Framförallt för nyanlända invandrare och ungdomar innebar krisen att arbetsmarknaden i stort sett var helt stängd. Den bristande arbetslivserfarenheten för dessa grupper innebar också ofta att man inte var kvalificerad för arbetsmarknadsersättning. Vilka förändringar skedde då för grupperna under 1990-talet i de tre välfärdsdimensioner som vi ska studera?

\section{Unga}

Under 1990-talet sjönk sysselsättningsgraden markant bland unga vuxna och andelen arbetssökande fördubblades. Till skillnad från den övriga befolkningen innebar dock inte krisen i första hand att de unga blev arbetslösa utan snarare att det dröjde innan de kom in på arbetsmarknaden, genomsnittsåldern för arbetsmarknadsinträdet steg. Under 1990-talet valde också allt fler ungdomar att gå vidare till högre studier, vilket möjliggjordes bl.a. med utbyggnaden av de regionala högskolorna. Andelen 25-åringar med erfarenhet av högskolestudier ökade under perioden från 25 till 39 procent (SOU 2001:79). Den ökade tiden i utbildning är naturligtvis delvis en förklaring till det senarelagda arbetsmarknadsinträdet men det är också en följd av att arbetsmarknaden var stängd för många ungdomar. 
Den ökade genomsnittsåldern för inträdet på arbetsmarknaden innebar att unga även i ekonomiskt avseende förlorade i förhållande till den övriga befolkningen under decenniet. Detta avspeglar sig såväl i disponibel inkomst som i socialbidragsberoende. Andelen som saknade en ekonomisk buffert vid oförutsedda händelser (en s.k. kontantmarginal) var också högre bland unga än övriga vid 1990-talets slut. ${ }^{1}$ Men tillgången till kontantmarginal förändrades inte relativt den övriga befolkningen (undantaget pensionärer), vilket möjligen till viss del kan förklaras av att ungdomar i högre grad än tidigare bodde kvar hos sina föräldrar vid slutet av decenniet (Börjeson 2001) och att ungdomar ofta får ekonomiskt stöd av föräldrarna (Fritzell \& Lennartsson 2005).

Gruppen unga har, av naturliga skäl, i genomsnitt bättre hälsa än befolkningen i stort. Den självskattade fysiska hälsan försämrades emellertid något under 1990talet, dock inte i högre grad än för den övriga befolkningen. Mer anmärkningsvärt är att unga människors psykiska hälsotillstånd försämrades påtagligt. Det senare handlar om en längre trend som tycks ha accelererat under 1990-talet (SOU 2001:79). Ökningen är sannolikt kopplad till såväl den minskade arbetsmarknadsförankringen som de försämrade ekonomiska resurserna i gruppen. I en nyligen publicerad statlig utredning om ungdomars psykiska ohälsa hävdas det att

1 Att ha en sådan ekonomisk buffert är centralt för möjligheten att kontrollera och styra sina livsvillkor. Kontantmarginalen i SCB:s ULFundersökning, på vilken dessa analyser baserar sig, motsvarade 12000 kronor åren 1990/1991 och 14000 kronor åren 1998/1999. det försämrade hälsoläget sannolikt också hänger ihop med en samhällsutveckling präglad av ökad individualisering (SOU 2006:77). Utredaren Sven Bremberg menar, på basis av jämförelser med andra länder, att det svenska samhället är extremt präglat av sekulära-rationella värderingar, där individuellt självförverkligande har hög prioritet. Ett sådant samhälle tenderar att ge ökad psykisk ohälsa i befolkningen i allmänhet och hos ungdomar i synnerhet.

\section{Utrikesfödda}

Utrikesfödda, speciellt invandrare från icke-europeiska länder, hade även före krisen en svag ställning på arbetsmarknaden, med hög arbetslöshet och låga löner. De stora förändringarna på 1990-talets arbetsmarknad gjorde att denna grupp lönemässigt ytterligare halkade efter den övriga befolkningen (le Grand \& Szulkin 2002). Under sysselsättningskrisen var också flyktinginvandringen till Sverige som störst. Dessa flyktingar, som huvudsakligen kom från Bosnien, Irak och Somalia (SCB 2006a), hade små möjligheter att få fotfäste på arbetsmarknaden och var i stort sett hänvisade till att leva på socialbidrag. Sammantaget innebar detta att sysselsättningsgraden i gruppen utrikesfödda totalt sett sjönk från 70 till 55 procent, och andelen arbetssökande fördubblades och var i slutet av decenniet ungefär 15 procent (SOU 2001:79). I likhet med unga vuxna hade alltså många invandrare svårt att överhuvudtaget ta sig in på arbetsmarknaden. Edin och Åslund (2001) visar att för de personer som kom till landet i början av decen- 
niet var arbetsmarknadsdeltagandet fortfarande mycket lågt vid slutet av 1990-talet. Också deras analyser i övrigt visar den centrala betydelsen av vistelsetid i landet för att förstå variationen inom gruppen utrikesfödda vad gäller sysselsättningsnivåer och inkomster från arbete.

Högre arbetslöshet och lägre sysselsättningsgrad ledde till att framförallt utrikesföddas förvärvsinkomster inte bara sjönk under decenniet utan dessutom halkade efter befolkningen i övrigt. Den sämre ekonomiska situationen för denna grupp visar sig också i att andelen som saknade kontantmarginal i slutet av decenniet var högre än i den övriga befolkningen (SOU 2001:79). Till skillnad mot vad som var fallet för unga så var den relativa utvecklingen vad gäller kontantmarginal dessutom sämre för utrikesfödda än för övriga.

Under hela 1990-talet hade utrikesfödda också generellt en sämre självskattad hälsa än den övriga befolkningen och den självskattade hälsan för gruppen försämrades dessutom under decenniet. Detta var dock del av en mer allmän trend, vilket betyder att försämringen, relativt sett, inte var större för utrikesfödda än för den övriga befolkningen. Däremot halkade utrikesfödda efter den övriga befolkningen vad gäller andelen som upplevde ängslan och oro. Även om denna försämring också bland utrikesfödda sannolikt var kopplad till förändringar på arbetsmarknaden och i tillgången till ekonomiska resurser så är det knappast hela sanningen. När det gäller utrikesfödda i allmänhet och nyanlända i synnerhet kan ökningen av ängslan och oro och andra indikatorer på nedsatt psykisk hälsa sannolikt till viss del hänföras till den spe- ciella livssituation som präglar tillvaron för många i gruppen, med oro för egen, familjens eller släktingars framtid. Genom att en så stor andel av de invandrare som kom under första halvan av 1990-talet var flyktingar (Appelqvist 2000) verkar det också rimligt att tro att erfarenheten av krig och våldshändelser är en viktig komponent för förståelsen av gruppens hälsostatus. Också bland flyktingbarn har man kunnat påvisa starka effekter på den mentala hälsan med tydliga post-traumatiska stressymptom, på längre sikt verkar dock dessa effekter avta betydligt (Hjern \& Angel 2000).

\section{Ensamstående mödrar}

Ensamstående mödrar i Sverige har sedan länge haft en relativt hög förvärvsarbetsfrekvens (Hobson \& Takahashi 1997, se också Kungliga Socialstyrelsen 1957). Under 1990-talet minskade dock andelen förvärvsarbetande också i den här gruppen. Det som emellertid framförallt utmärkte arbetsmarknadssituationen för ensamstående mödrar vid decenniets slut var, för det första, att en klart större andel av de icke förvärvsarbetande, jämfört med decenniets början och med befolkningen i övrigt, definierade sig som arbetslösa och arbetssökande (Gähler 2001). ${ }^{2}$ För det andra försvagades ställningen på arbetsmarknaden för dem som hade arbete. Andelen heltidsanställda av de förvärvsarbetande minskade

2 Enligt SCB:s ULF-undersökningar åren 1998/1999 saknade var sjunde ensamstående mor arbete och »var arbetslös, sökte eller väntade på arbete». 
och andelen tidsbegränsat anställda ökade kraftigt (SOU 2001:79). De ensamstående mödrarnas försämrade ställning på arbetsmarknaden har givits olika förklaringar, t.ex. att de ekonomiska drivkrafterna för förvärvsarbete är svaga för ensamstående mödrar, att arbetsgivare pga. låg flexibilitet och hög frånvaro i gruppen skulle vara tveksamma till att anställa (och behålla) ensamstående mödrar och att ensamstående mödrar oftare saknar lämplig utbildning (för en diskussion kring dessa förklaringars giltighet, se Gähler 2001).

Oavsett skäl så är den försvagade anknytningen till arbetsmarknaden naturligtvis en starkt bidragande orsak till den försämring $\mathrm{i}$ ekonomiska resurser som många ensamstående mödrar erfor under 1990-talet. Den justerade disponibla inkomsten minskade under perioden. Dessutom ökade andelen ensamstående mödrar som saknade en kontantmarginal, från en tredjedel till hälften, och andelen som haft svårigheter att klara de löpande utgifterna under det senaste året ökade från ca 45 till drygt 60 procent. ${ }^{3}$ Under hela decenniet var detta nivåer som låg klart högre än för andra grupper men också förändringen under tidsperioden var klart mer negativ för de ensamstående mödrarna. Det bör påpekas att ensamstående mödrars försämrade resurser inte kan förklaras av att gruppens sociala och demografiska sammansättning skulle ha ändrats (Gähler 2001).

Enligt Sørensen (1994) är tre faktorer

3 Dessutom hänvisade en ökande andel av de mödrar som uppgav att de hade en kontantmarginal till olika former av lån medan allt färre hade pengarna på ett eget bankkonto. viktiga för förståelsen av de ensamstående mödrarnas dåliga ekonomiska situation: i) ensamstående mödrar är kvinnor och kvinnor har lägre arbetsinkomster än män (som en följd av lägre förvärvsarbetsfrekvens, kortare arbetstider och lägre löner). ii) ensamstående mödrar är ensamma familjeförsörjare, vilket gör dem mer sårbara vid t.ex. arbetslöshet eller sänkningar i olika bidragsnivåer och att de går miste om de skalfördelar som det kan innebära att vara flera inkomsttagare i hushållet. ${ }^{4}$ iii) ensamstående mödrar har oftast det huvudsakliga ekonomiska ansvaret för barnen. Även om de frånlevande fäderna bidrar ekonomiskt till barnens försörjning så motsvarar detta ofta inte det ansvar som fäder i tvåföräldrafamiljer tar. Sørensens lika enkla som goda sammanfattning belyser tydligt varför ensamstående mödrar i många avseenden är mer sårbara än andra grupper för en ekonomisk recession.

Flera studier har också visat att ensamstående mödrar har sämre hälsa än andra grupper (Fritzell \& Burström 2006, Ringbäck Weitoft et al. 2000, Ringbäck Weitoft et al. 2002). Under 1990-talet försämrades också situationen för de ensamstående mödrarna i relation till befolkningen i stort. Andelen som uppgav dålig hälsa, ängslan, oro, ångest och långvarig sjukdom ökade i högre utsträckning än för befolkningen i allmänhet (SOU 2001:79). En ny studie som

4 Skalfördelarna refererar till sådana kostnader som är gemensamma för hushållsmedlemmarna och som inte ökar eller ökar relativt lite med fler inkomsttagare i hushållet. Exempel på sådana utgifter är prenumeration på dagstidning, telefonabonnemang och tv-licens. 
jämför ensamstående och sammanboende mödrars hälsoutveckling mellan ca 1980 och år 2000 visar dock i huvudsak stabila skillnader, till de ensamstående mödrarnas nackdel beträffande såväl självskattad hälsa, slutenvård som dödlighet (Fritzell et al. kommande). Två möjliga huvudorsaker till de ensamstående mödrarnas relativt dåliga hälsa har pekats ut: i) att det är en konsekvens av andra förhållanden som följer av att man lever som ensamstående mor, t.ex. försämrade socioekonomiska förhållanden, socialt stigma, de påfrestningar som en skilsmässa kan innebära, ett sämre socialt skyddsnät samt den ökade stress som bl.a. en stor arbetsbörda kan leda till. ii) att kvinnor med dålig hälsa oftare är eller blir ensamstående mödrar (för empiriska prövningar av dessa förklaringars giltighet, se bl.a. Gähler 2006, Ringbäck Weitoft et al. 2000, Ringbäck Weitoft et al. 2002).

\section{Vad hände sedan?}

Förändringari de tre gruppernas levnadsförhållanden mellan 1998/1999 och 2004/2005

Vid sidan om en konjunktursvacka med åtföljande börsras under millenniets första år har den ekonomiska konjunkturen, i form av BNP-utvecklingen, som helhet varit relativt gynnsam under det innevarande decenniets första hälft (SCB 2006b). Under perioden 1997-2006 minskade också arbetslösheten i landet, från åtta till drygt fem procent och antalet sysselsatta har ökat kraftigt (SCB 2007). Befolkningens disponibla inkomster har också ökat, men inkomstklyftorna har inte minskat till föjd av den ökade sysselsättningen. Den långsiktiga trenden med ökande inkomstskillnader fortsatte fram till millennieskiftet varefter spridningen har stabiliserats på en för Sverige hög nivå (SCB 2006c). Folkhälsans utveckling under senare år ger en mer splittrad bild. Dödligheten har minskat och medellivslängden har följaktligen ökat. Samtidigt har ett antal åkommor och sjukdomar ökat i omfattning. Från mitten av 1980talet till 2002/2003 uppger en kontinuerligt ökande andel i befolkningen att de lider av långvarig sjukdom eller besvär. Sedan mitten av 1990-talet har också andelen med dålig självskattad hälsa ökat. Likaså har utvecklingen av den psykiska hälsan varit negativ. Andelen i befolkningen som lider av ängslan, oro och ångest respektive trötthet och sömnbesvär har ökat kontinuerligt sedan slutet av 1980-talet men ökningen har varit särskilt stor sedan mitten av 1990talet (Socialstyrelsen 2005).

Syftet här är alltså att visa hur utvecklingen har sett ut för ungdomar, utrikesfödda och ensamstående mödrar sedan millennieskiftet. I ett första steg jämför vi därför situationen för de tre grupperna med befolkningen i stort vid två tidpunkter, 1998/1999 och 2004/2005. Som ungdomar räknar vi personer mellan 20 och 29 år. Gruppen utrikesfödda är förstås mycket heterogen. Närmast oavsett vilket utfall som studeras har det visat sig att utrikesfödda som kommer från olika regioner med olika ekonomiska förhållanden har olika levnadsförhållanden (se t.ex. Integrationsverket 2004). För att i någon mån fånga upp detta särskiljer vi två grupper av utrikesfödda, där den första gruppen har invandrat från något av de gamla OECD-länderna (dvs. hög- 
inkomstländer i Västeuropa och Nordamerika inkl. Australien) medan den andra gruppen huvudsakligen kommer från medeloch låginkomstländer (Afrika, Asien, det forna Östeuropa (inkl. Turkiet) och Sydamerika). Med ensamstående mödrar avses kvinnor som bor ensamma med minst ett barn under 18 år, som bor med mamman minst halva tiden (för en mer detaljerad variabelbeskrivning, se Appendix).

\section{Arbetsmarknad och sysselsättning ${ }^{5}$}

Den förbättrade ekonomiska konjunkturen avspeglar sig i utvecklingen på arbetsmarknaden. Av Tabell 1 framgår att andelen sysselsatta i befolkningen (20-65 år) har ökat (bland kvinnor) sedan slutet av 1990-talet medan framförallt långtidsarbetslösheten har sjunkit något. Kvinnors förankring på arbetsmarknaden har också förbättrats $\mathrm{i}$ det att andelen förvärvsarbetande i tidsbegränsad anställning har minskat något. Det senare resultatet är intressant eftersom det tyder på ett trendbrott. Under 1990-talet ökade andelen med tidsbegränsade anställningar mycket kraftigt (Fritzell \& Lundberg 2000).

5 Vi har valt att utgå från SCB:s ULF-undersökningar i detta avsnitt. Många av de övergripande förändringar som vi redovisar kan självfallet hämtas från den officiella statistiken, de s.k. arbetskraftsundersökningarna (AKU). Definitionerna av olika begrepp varierar något mellan de olika undersökningarna (se Åberg \& Nordenmark 2000 för en diskussion). De procenttal som redovisas här kan därför avvika från den officiella statistiken.
En närmare granskning av de tre grupper som står i fokus här ger emellertid en bild som inte är helt entydig. Bland de unga vuxna och de ensamstående mödrarna är andelen som förvärvsarbetar i stort sett oförändrad. Det finns dock en tydlig tendens till att utvecklingen för unga män och kvinnor skiljer sig åt, där kvinnorna fått en fastare förankring på arbetsmarknaden medan männen, om något, har försämrat sin position. Färre unga kvinnor är långtidsarbetslösa och tidsbegränsat anställda. Sysselsättningsgraden har också ökat. För de unga männen är tendensen den rakt motsatta, med stabil arbetslöshetsnivå, minskad sysselsättning och ökad andel tidsbegränsat anställda (dessa förändringar är emellertid inte statistiskt säkerställda). Även om det handlar om mycket låga tal bör det noteras att andelen förtidspensionärer (personer med sjuk- och aktivitetsersättning) fördubblats bland de unga. Till viss del har dessa tal påverkats av att denna grupp sedan 2003 även omfattar personer med tidsbegränsad aktivitetsersättning. ${ }^{6}$ Likväl är det oroande att antalet personer mellan 20 och 29 år med aktivitetsersättning har stigit från 12600 personer 1998 till 21400 år 2005 (se Försäkringskassan 2006).

För de utrikesfödda har utvecklingen på arbetsmarknaden under senare år varit mer entydigt positiv. Andelen sysselsatta

6 Aktivitetsersättning för unga har ersatt förtidspension och är ett stöd som ges till unga med varaktigt eller tidsbegränsad nedsatt arbetsförmåga på grund av sjukdom eller annan nedsättning av den fysiska eller psykiska prestationsförmågan (Försäkringskassan 2006). 


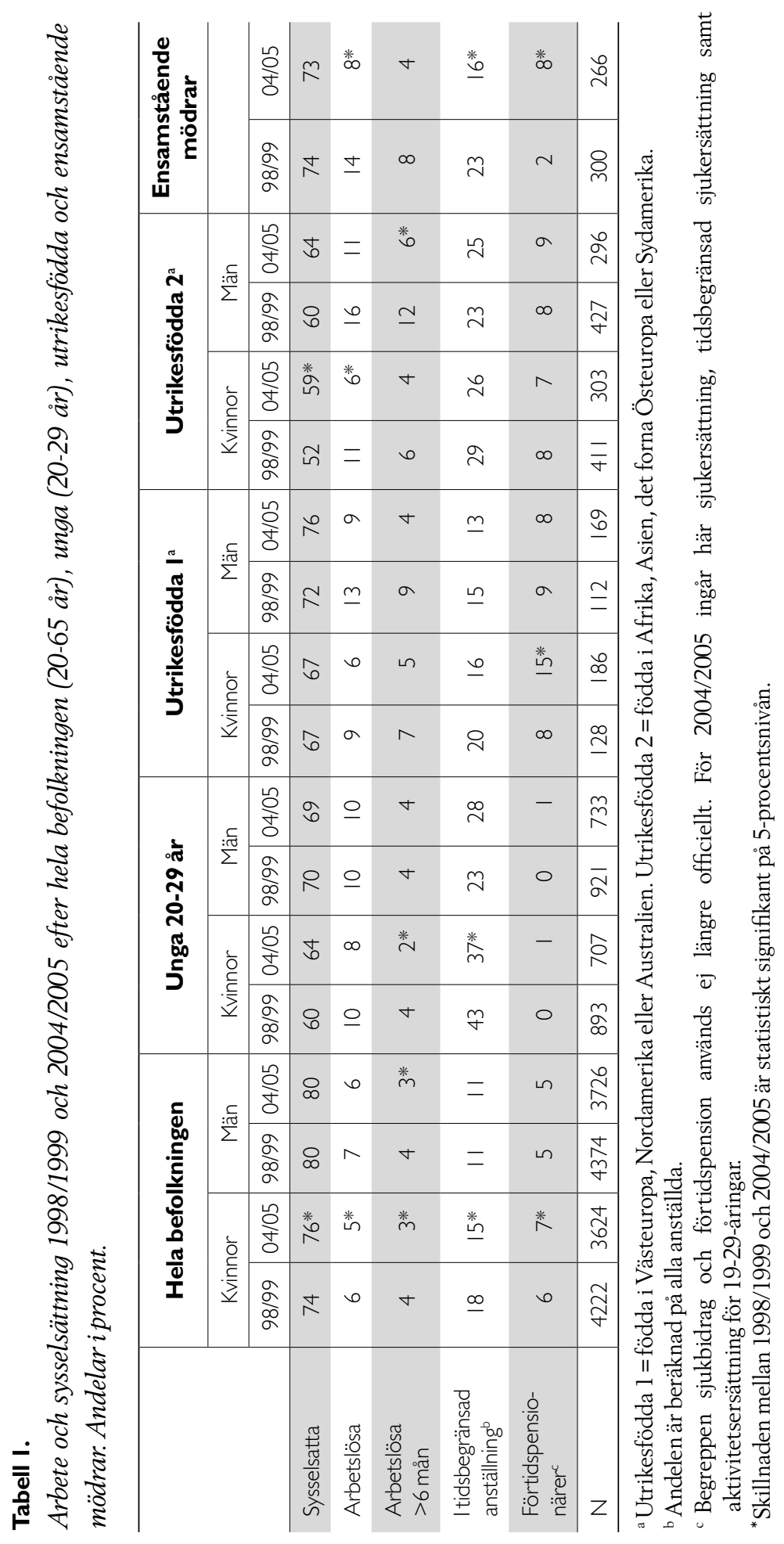

Fritzell, Gähler \& Nermo: Vad hände med 1990-talets stora förlorargrupper? Välfärd och ... 
har ökat och arbetslösheten har sjunkit (även om förändringarna i de flesta fall inte är statistiskt säkerställda), oberoende av vilken grupp av utrikesfödda som står i fokus. Denna utveckling betyder bl.a. att skillnaden mellan män och kvinnor som invandrat från medel- och låginkomstländer å ena sidan, och befolkningen i allmänhet å andra sidan är betydligt mindre åren 2004/2005. Vi har också analyserat om de positiva sysselsättningseffekterna för invandrare enbart är en effekt av längre vistelsetid, vad vi skulle kunna kalla en sammansättningseffekt. Det visar sig att så inte är fallet. Såväl inom gruppen med vistelsetid i landet upp till fem år, som mellan sex och tio år finner vi en markant uppgång i sysselsättningen mellan våra två tidpunkter. Faktum är att det är i gruppen som varit i landet elva år eller längre som sysselsättningsuppgången är som mest blygsam.

Det bör dock understrykas att även om utvecklingen på arbetsmarknaden under det nya millenniets första år har varit positiv för dem som invandrat från Afrika, Asien, det forna Östeuropa, eller Sydamerika (särskilt för kvinnorna), så är andelen sysselsatta fortfarande klart lägre än för befolkningen i övrigt. Det är också mycket vanligare med arbetslöshet, tidsbegränsade anställningar och förtidspension bland invandrare. Andelen förtidspensionärer är allra högst bland kvinnor som invandrat från länder i Västeuropa, Nordamerika eller Australien. Detta beror i huvudsak på en stor andel förtidspensionärer bland kvinnor födda i Finland.

Liksom var fallet ovan för unga så döljer stabiliteten $\mathrm{i}$ andelen sysselsatta bland ensamstående mödrar andra intressanta mönster. Arbetslösheten och andelen förvärvsarbetande i tidsbegränsad anställning har till exempel minskat kraftigt under perioden. Nedgången i arbetslöshet för gruppen tycks dock inte enbart vara av godo. Åtminstone inte om man inte räknar förtidspension som ett positivt alternativ. Ökningen i andelen förtidspensionärer, från drygt två till knappt åtta procent, motsvarar till fullo minskningen i andelen arbetslösa.

\section{Ekonomi}

Hushållets ekonomiska situation betingas givetvis i hög grad av hushållsmedlemmarnas arbetsinkomster. Följdriktigt har förvärvsarbetande i allmänhet högre inkomster än de som, av olika skäl, står utanför arbetsmarknaden (SCB 2006c). Den förbättrade situationen på arbetsmarknaden har således åtföljts av förbättrade ekonomiska villkor för befolkningen i stort. Andelen som saknar kontantmarginal har gått ned och färre har ekonomiska svårigheter. Också inkomstutvecklingen är påfallande positiv under tidsperioden. Trots att vi justerar för inflation ökar den ekvivalerade disponibla medianinkomsten med runt 20 procent. ${ }^{7}$ På så sätt avviker utvecklingen under det nya millenniets inledning radikalt från 1990-talet då medianinkomsterna i stort sett var identiska i början och slutet av decenniet.

7 Detta är en utveckling som överensstämmer väl med data från SCB:s inkomstfördelningsundersökningar. 


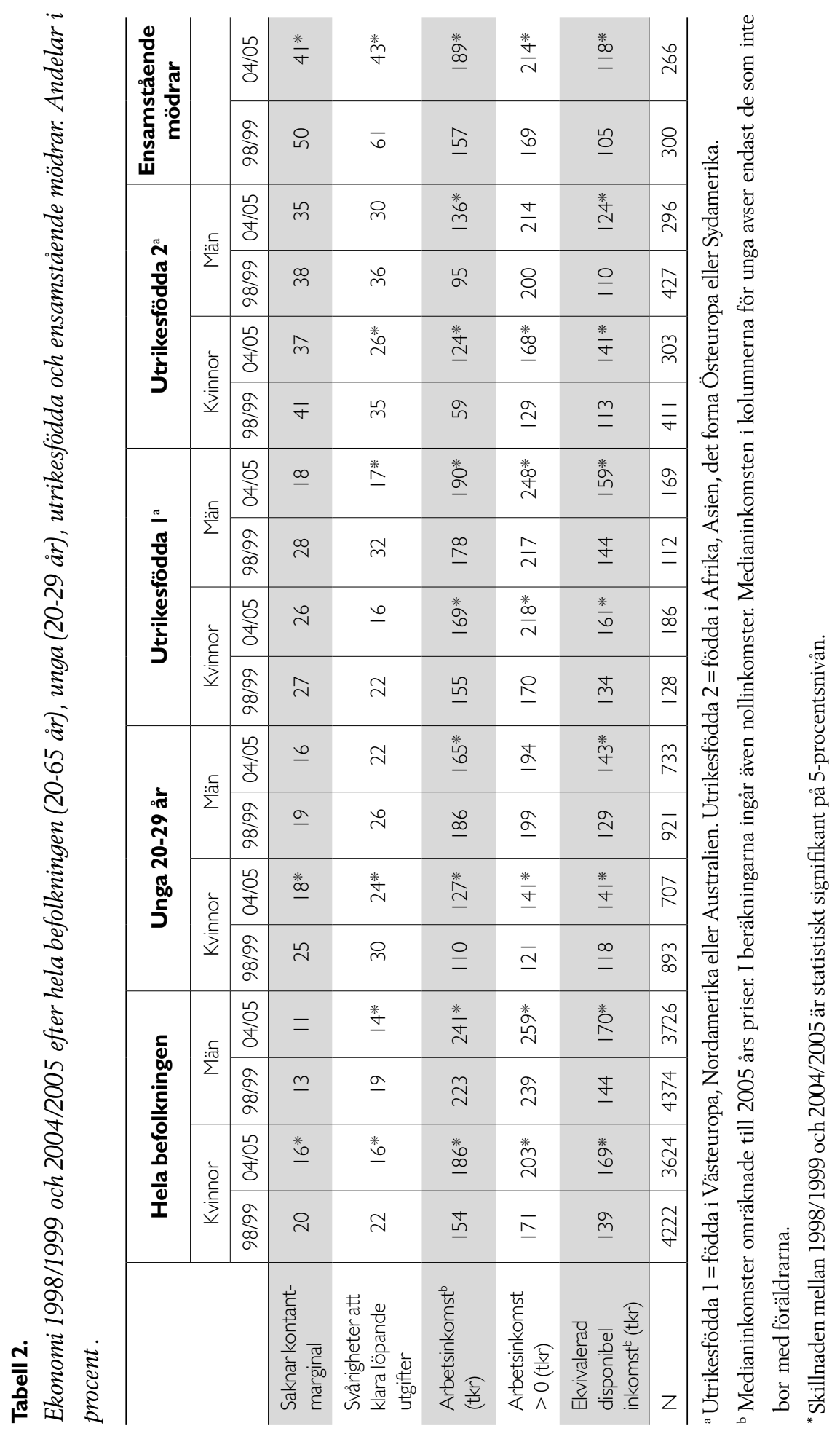

Fritzell, Gähler \& Nermo: Vad hände med 1990-talets stora förlorargrupper? Välfärd och ... 
Den goda konjunkturen på arbetsmarknaden avspeglar sig också i kraftigt ökade reallöner. Den generella ökningen i arbetsinkomster är emellertid också delvis en följd av att fler är i arbete (notera att vi här inkluderar också dem utan arbete). Man kan speciellt notera att kvinnors arbetsinkomster har närmat sig mäns arbetsinkomster.

Också för de grupper som står i fokus här har den ekonomiska situationen förbättrats avsevärt under det nya millenniets första år. Genomgående har andelen som saknar kontantmarginal respektive haft svårigheter att klara de löpande utgifterna under det senaste året minskat. Förbättringarna är särskilt stora för de ensamstående mödrarna men också övriga grupper har upplevt förbättringar som oftast är i paritet med eller större än för befolkningen i allmänhet (även om förändringarna inte alltid är statistiskt säkerställda). Samtidigt är det värt att påpeka att fyra av tio ensamstående mödrar fortfarande åren 2004/2005 saknar möjlighet att få fram en förhållandevis ringa summa pengar vid oförutsedda utgifter och en lika stor andel har haft svårt att klara de löpande utgifterna. Också för den överlägset största av våra två invandrarkategorier, dvs. personer från Afrika, Asien, det forna Östeuropa och Sydamerika, ligger dessa indikatorer på ekonomiska svårigheter mycket högt. En dryg tredjedel av dessa kvinnor och män uppger t.ex. att de saknar en ekonomisk buffert.

När det gäller arbetsinkomsternas utveckling är utvecklingen mindre entydig. Medianarbetsinkomsten har stigit för unga kvinnor medan den sjunkit för unga män. ${ }^{8}$ Däremot är förändringarna mycket positiva för utrikesfödda kvinnor och män, samt för ensamstående mödrar. I samtliga fall finner vi också en förbättring av den disponibla inkomsten under tidsperioden. Samtidigt kan vi konstatera att några grupper har fortsatt att halka efter då deras disponibla inkomstutveckling inte varit fullt så god som för befolkningen i gemen. Detta gäller såväl unga som utrikesfödda män och ensamstående mödrar, för vilka grupper ökningen av den disponibla inkomsten stannat vid drygt tio procent under perioden. Unga och utrikesfödda kvinnor har haft en inkomstutveckling som, relativt sett, är i paritet med befolkningen i dess helhet. Inte för någon av de sju kategorier vi särredovisar finner vi emellertid en förändring av medianinkomsterna i absoluta tal som når upp till utvecklingen för befolkningen i stort (inom respektive kön). Våra grupper tycks alltså ha svårt att närma sig, än mindre komma ifatt, den övriga befolkningen oavsett konjunktursvängningar. Här tycks med andra ord analysen av de disponibla inkomsternas utveckling ge en något motstridig bild i förhållande till indikatorerna på ekonomiska svårigheter eller arbetsinkomsternas utveckling.

Avslutningsvis bör vi säga något om relationen mellan arbetsinkomst och disponibel inkomst. Vi konstaterade inledningsvis att inkomster från arbete är betydelsefulla för individers ekonomiska situation. Det kan då synas paradoxalt att den disponibla inkomsten ökat förhållandevis mycket

\footnotetext{
8 Enligt data från SCB:s inkomstfördelningsundersökningar är könsskillnaderna i förändring över tid mindre men pekar åt samma håll.
} 
medan ökningen i arbetsinkomst varit blygsam för vissa grupper (t.ex. unga kvinnor) medan det motsatta förhållandet gäller för andra grupper (ensamstående mödrar). Skälet är att inkomster av arbete förvisso är viktiga för den disponibla inkomsten men att den senare också inkluderar andra typer av inkomster (arbetsrelaterade transfereringar ingår $\mathrm{i}$ arbetsinkomsten men däremot inte vissa andra bidrag, inte heller kapitalinkomster eller skatter). Om det skett förändringar i något av dessa avseenden så påverkar det sambandet mellan arbetsinkomst och disponibel inkomst. Låt oss exemplifiera med de ensamstående mödrarna. Denna grupp är starkt beroende av olika typer av välfärdssystem för sin försörjning (se Gähler 2001). Om försörjningen via andra försörjningskällor minskar som en följd av ökade löneinkomster, eller pga. politiskt beslutade ändringar i transfereringar och skatter, så kan den disponibla inkomsten lämnas opåverkad eller öka relativt lite. För de unga gäller det rakt motsatta. Här har uppenbarligen andra typer av positiva transfereringar delvis kompenserat gruppen för en svag utveckling av arbetsinkomsten. Dessutom är den disponibla inkomsten justerad för hushållsstorlek med hjälp av en ekvivalensskala. Om hushållsstorleken ökar eller minskar mellan åren så påverkar det givetvis relationen mellan de båda inkomstslagen.

\section{Hälsa}

Den positiva utvecklingen på arbetsmarknaden och förbättringarna i de ekonomiska villkoren har, paradoxalt nog, inte resulte- rat i en förbättrad hälsa hos befolkningen. Åtminstone inte så länge vi, som här, koncentrerar oss på sjuklighet och självskattad ohälsa snarare än dödlighet. I Tabell 3 framgår att andelen kvinnor och män i befolkningen vars självskattade hälsa är sämre än god respektive känner besvär av ängslan, oro och/eller ångest är relativt stabil mellan tidsperioderna medan andelen som lider av långvarig sjukdom har ökat betydligt. ${ }^{9}$ Ökningen av andelen med svåra besvär av långvarig sjukdom är svagare men ändå tydlig. Sammantaget rimmar dessa resultat väl med ökningen i antalet förtidspensionerade.

Hur har då hälsoutvecklingen sett ut för de unga, de utrikesfödda och de ensamstående mödrarna? Bland de unga har mycket lite hänt under tidsperioden. Inga statistiskt säkerställda förändringar kan noteras. I den här gruppen har emellertid främst det psykiska välbefinnandet stått i fokus i debatten. Sedan en längre tid tillbaka har det psykiska hälsotillståndet i gruppen kontinuerligt försämrats (Fritzell et al. 2007). Under perioden 1998/1999-2004/2005 har dock andelen som uppger sig lida av ängslan, oro och/eller ångest inte ökat nämnvärt utan stabiliserats på en hög nivå. Samtidigt bör det noteras att dessa problem är vanligare bland unga kvinnor än bland kvinnor i befolkningen i stort. För unga män är andelen lika hög som för män i hela befolkningen. Detta trots att man tidigare kunnat konstatera att problemet med ängslan, oro

9 Denna utveckling är emellertid behäftad med viss osäkerhet då frågeformuleringen har förändrats mellan undersökningsåren 1998/1999 och 2004/2005 (se Appendix). 


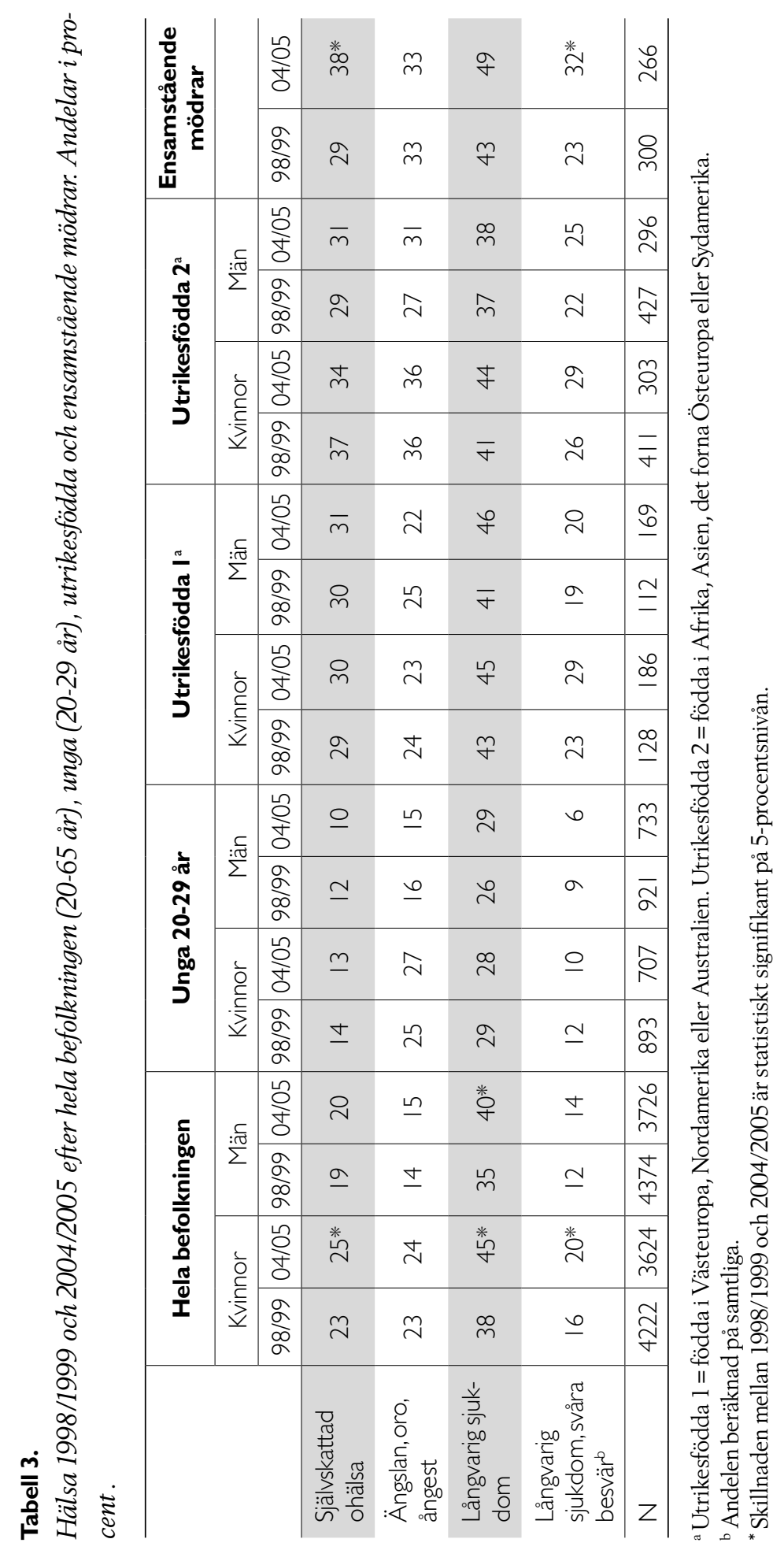

Socialvetenskaplig tidskrift nr 2-3 2007 
och/eller ångest ökat med stigande ålder (ibid.). En närmare analys stöder arbetsmarknadsförankring som en viktig faktor för att förstå ungdomars psykiska ohälsa. Vid båda tillfällena och för båda könen är risken för psykisk ohälsa betydligt lägre bland dem med sysselsättning än bland andra unga vuxna (syns ej i tabellen).

Utvecklingen för de utrikesfödda ser ut ungefär som för befolkningen i allmänhet men förändringen når inte i något fall statistisk signifikans. Nivån på ohälsan är dock fortsatt klart högre bland de utrikesfödda än i befolkningen i gemen. Skillnaden är särskilt slående bland männen, där båda invandrarkategorierna avviker kraftigt från män i allmänhet, med klart sämre hälsa. Detta är allra tydligast bland de män som invandrat från Afrika, Asien, det forna Östeuropa eller Sydamerika. Bland dessa är det t.ex. mer än dubbelt så vanligt med ängslan, oro och ångest än bland män i hela befolkningen. Det är också betydligt vanligare med svåra besvär av långvarig sjukdom.

Det mest intressanta resultatet i Tabell 3 är kanske ändå utvecklingen för de ensamstående mödrarna. I denna grupp är förändringarna som allra tydligast, med kraftiga försämringar av den självskattade hälsan och en ökning i andelen som lider av svåra besvär av långvarig sjukdom. Åren 2004/2005 uppgav nära fyra av tio ensamstående mödrar att deras hälsa var sämre än god, var tredje led av ängslan, oro och/eller ångest, hälften led av en långvarig sjukdom och en tredjedel hade svåra besvär av en sådan sjukdom. Detta är mycket höga andelar, alldeles särskilt om man betänker att ensamstående mödrar i allmänhet är relativt unga.

\section{Ofärdens samgång}

När välfärdens fördelning analyseras har den svenska, eller skandinaviska, välfärdstraditionen traditionellt ställt sig avvisande till att sammanfatta välfärdens dimensioner i ett enda välfärdsmått. Anledningen till detta är att det är mycket svårt att rangordna välfärdsproblem inom olika områden och exempelvis hävda att en rik och sjuk person har en högre (eller lägre) grad av välfärd än en fattig och frisk individ (för en utförlig diskussion se t.ex. Atkinson et al. 2002, Fritzell \& Lundberg 2005).

Trots det är det rimligt att hävda att varje ytterligare välfärdsproblem är något negativt. Om två personer är lika fattiga men den ene också har allvarliga hälsoproblem så är, allt annat lika, levnadsnivån sämre för denne (Fritzell \& Lundberg 2000, se också Sen 1987). En annan infallsvinkel på denna problematik är att säga att det är möjligt att acceptera ojämlikhet inom ett område men att detta inte, i sin tur, får styra välfärdens fördelning inom ett annat område. Många anser att en viss grad av inkomstojämlikhet är acceptabel, eller t.o.m. nödvändig, men betydligt färre skulle vara beredda att påstå att plånbokens storlek är det som borde vara avgörande för vårt hälsotillstånd. Detta synsätt, att fördelningen inom ett fält inte ska få avgöra hur välfärden fördelas enligt en annan dimension, ligger till grund för Walzers (1983) rättviseteori.

Det finns med andra ord goda skäl att också studera om och hur arbetsmarknadsproblem, ekonomiska problem och hälsoproblem samvarierar. Är det så att de grupper som står i fokus här, unga vuxna, utrikesfödda och ensamstående mödrar, också 
är mer utsatta för samtidig ofärd? Är det så att olika välfärdsproblem tenderar att samvariera i högre (eller lägre) utsträckning för dessa grupper? Vilka förändringar över tid kan vi urskilja i dessa avseenden?

De indikatorer och klassificeringar vi valt ut är följande: de som varken är sysselsatta eller studerande anses ha "svag arbetsmarknadsförankring", de vars självskattade hälsa är sämre än god anses ha »nedsatt hälsau och de som saknar kontantmarginal anses ha "ekonomiska svårigheter «. ${ }^{10}$ Tabell 4 visar den kumulativa fördelningen av dessa problem på individnivå, dels för hela befolkningen, dels för unga vuxna, utrikesfödda och ensamstående mödrar. För befolkningen i stort är förändringarna mycket små, närmast försumbara. Ett i sig intressant resultat givet de goda tiderna. För våra tre grupper har emellertid andelen helt utan dessa problem genomgående ökat. I den meningen kan vi alltså säga att välfärdsnivån för 1990-talets förlorargrupper närmat sig befolkningens välfärdsnivå. Ändå kan vi inte entydigt säga att situationen för grupperna har förbättrats. Åtminstone inte för de utrikesfödda och de ensamstående mödrarna. Skälet är att andelen med tre problem också har ökat, särskilt bland ensamstående mödrar där en fördubbling har skett (från sex till tolv procent). Det finns alltså klara tendenser till

10 Man skulle i och för sig kunna ifrågasätta om en svag arbetsmarknadsförankring alltid är ett välfärdsproblem. De som väljer att vara hemarbetande eller att leva på sitt kapital kommer på så vis att ingå i vår problemgrupp. Dessa grupper är dock numerärt försumbara i våra analyser. en polarisering, där fler fått det bättre men där fler också fått det sämre. Även om förändringarna i några fall är relativt stora är antalet observationer som ligger till grund för analyserna relativt få varför endast fördubblingen av dem med tre problem bland ensamstående mödrar är statistiskt säkerställd. Viktigt att komma ihåg är dock att vi av de ökade andelarna utan problem för t.ex. invandrargrupperna borde förvänta oss en minskning av andelarna med tre problem, något som alltså inte alls sker.

Tvärtemot vad som ses som önskvärt utifrån Walzers teori om rättvisa har tidigare välfärdsstudier i Sverige tydligt visat att olika välfärdsdimensioner är positivt korrelerade med varandra (se t.ex. Erikson \& Tåhlin 1984, Fritzell \& Lundberg 2000). Inte minst brukar den ekonomiska dimensionen uppvisa ett starkt positivt samband med andra aspekter av välfärd och ofärd. I Tabell 5 redovisar vi hur dessa samband ser ut $\mathrm{i}$ befolkningen $\mathrm{i}$ stort och för våra tre grupper. ${ }^{11}$ Det första som framgår är att dessa ofärdsproblem hänger starkt samman. Detta gäller för alla våra grupper men också för befolkningen i stort. Delvis i linje med vad vi kan förvänta utifrån fördelningen av välfärdsproblemen i Tabell 4 visar också dessa korrelationsmatriser på starkare samband 2004/2005 än 1998/1999. Detta är framförallt tydligt för ensamstående mödrar och för utrikesfödda från Afrika, Asien, det forna Östeuropa och Sydamerika. Tidigare korrelationsanalyser av detta slag har givit vid handen att sambanden är

11 Sambanden är beräknade med s.k. gammakoefficienter. Ju högre värde desto starkare är indikatorerna kopplade till varandra. 


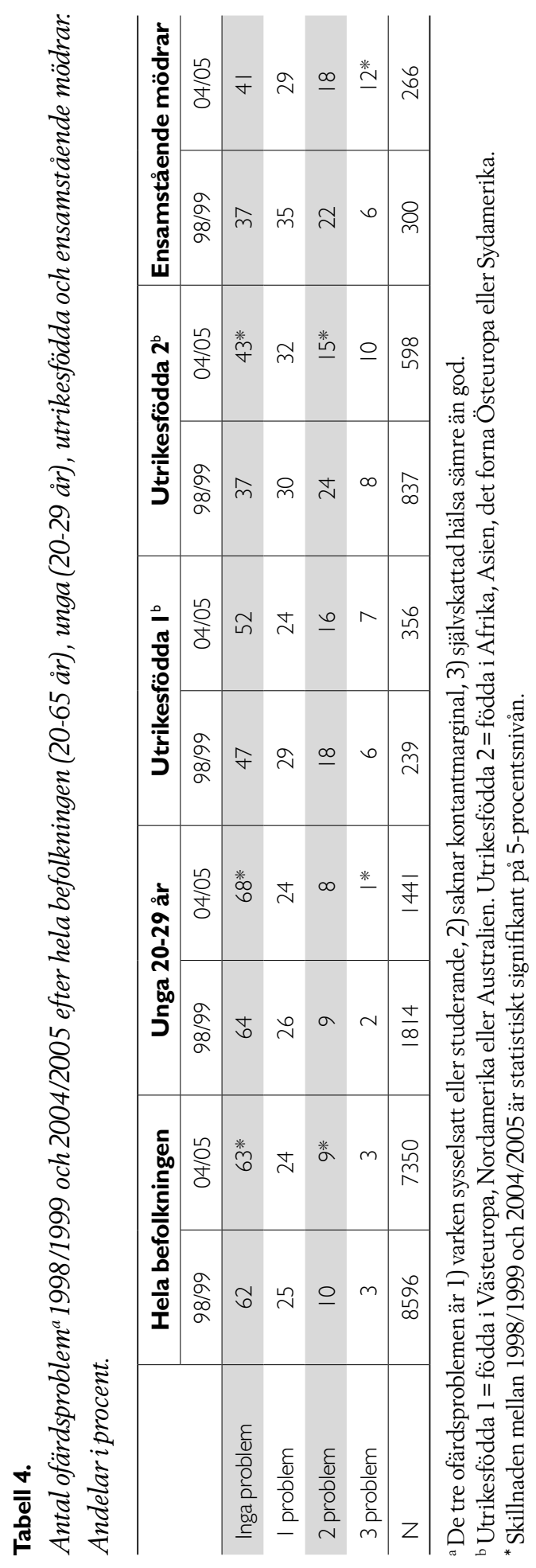

Fritzell, Gähler \& Nermo: Vad hände med 1990-talets stora förlorargrupper? Välfärd och ... 


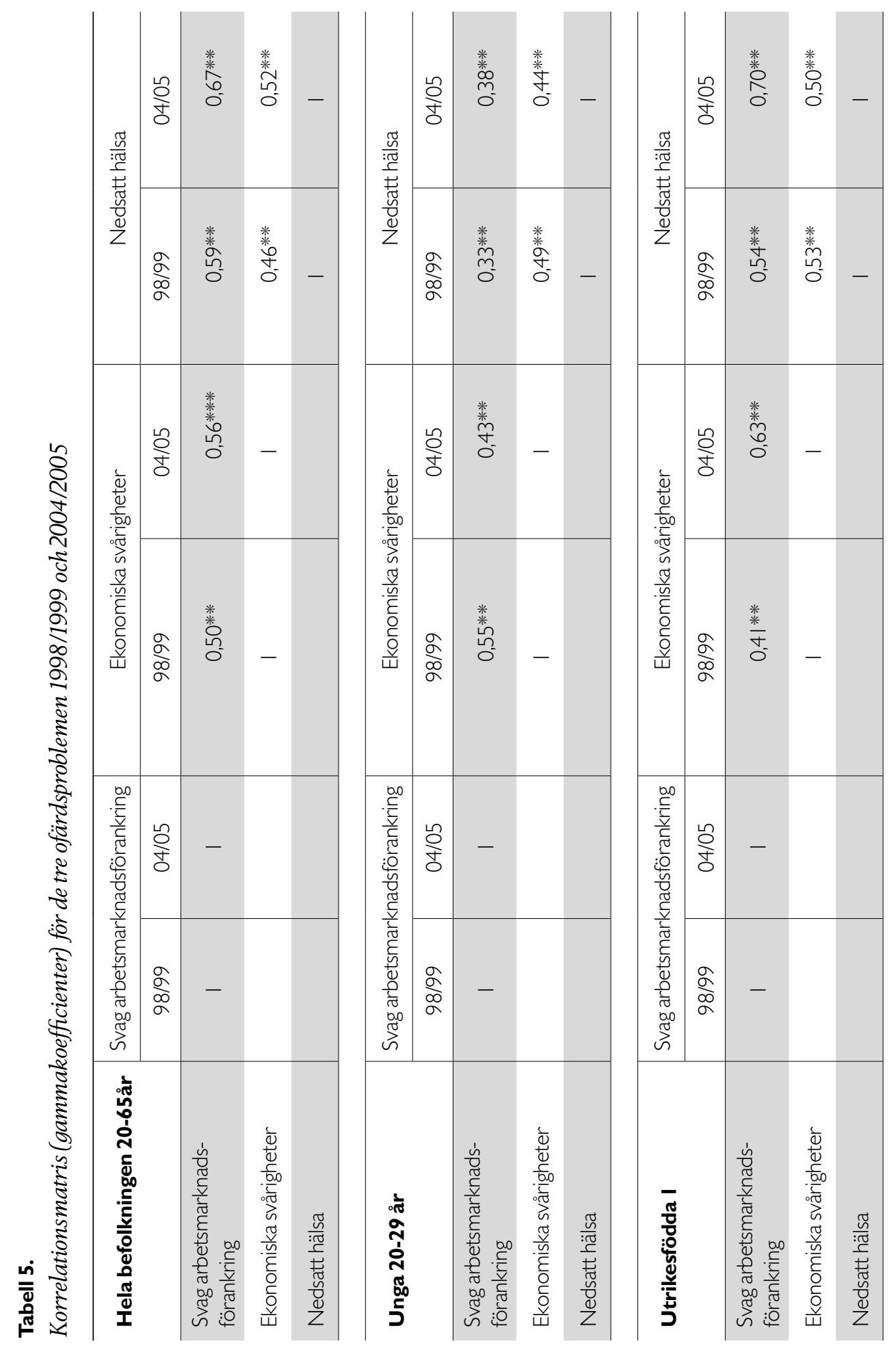

Socialvetenskaplig tidskrift nr 2-3 2007 


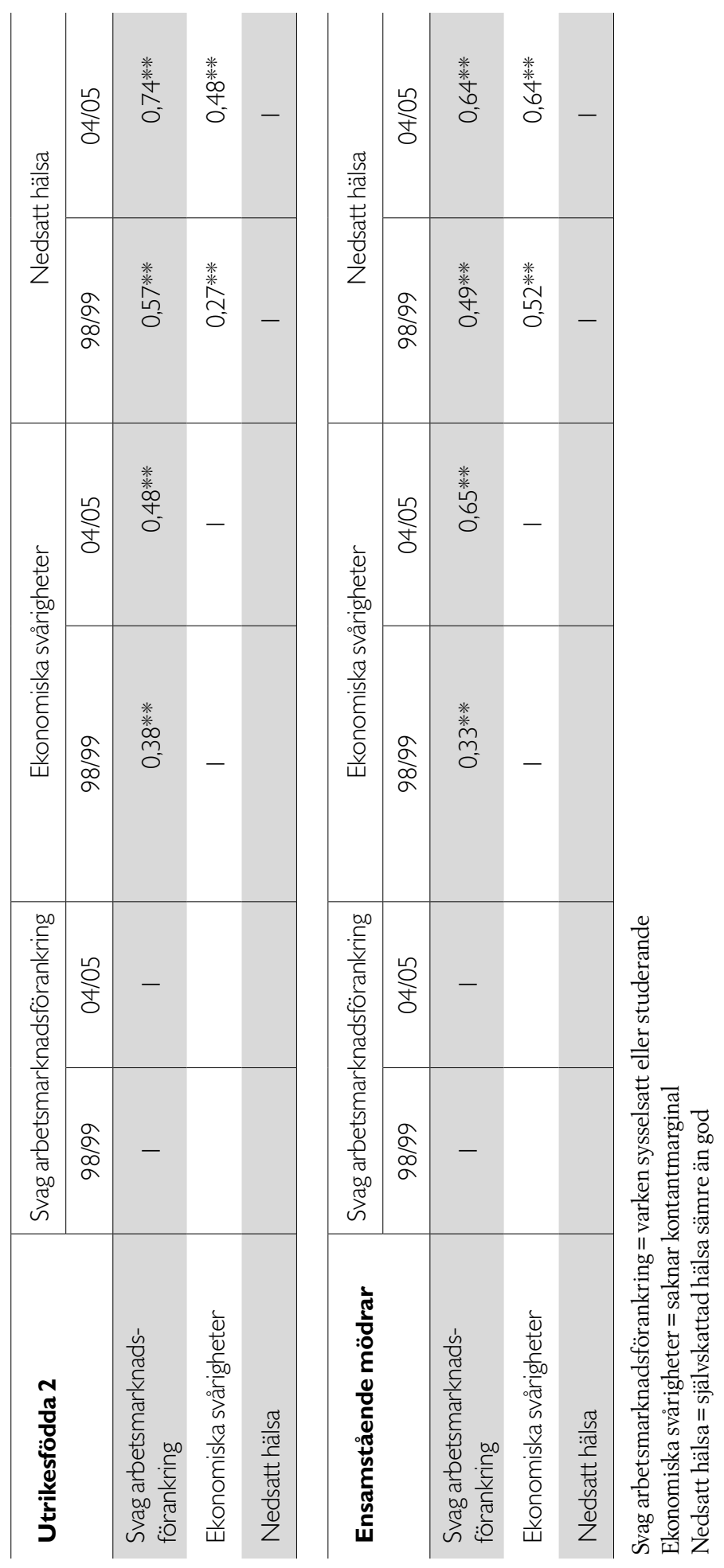

Fritzell, Gähler \& Nermo: Vad hände med 1990-talets stora förlorargrupper? Välfärd och ... 
stabila över tid. Erikson och Tåhlin (1984) fann att sambanden var ungefär lika starka vid slutet av 1960-talet som i början av 1980-talet trots att ofärdsproblemen minskat betydligt. Fritzell och Lundberg (2000) fann att sambanden var stabila vid en jämförelse före och efter 1990-talets krisår. Till skillnad från dessa tidigare analyser visar våra resultat att sambanden har förstärkts, framförallt för utrikesfödda och ensamstående mödrar. Också för befolkningen i stort ser vi att sambanden ökar i styrka mellan alla tre välfärdsdimensionerna. Detta visar att fortfarande runt 2005 har många ännu inte kunnat ta del av de goda tider som rått under senare år. Även om många också bland 1990-talets förlorargrupper fått det bättre under 2000-talets inledning, tycks vi ha fått en något större grupp som lider av flera samtidiga allvarliga välfärdsproblem.

\section{Sammanfattande diskussion}

För de tre välfärdsindikatorer som står i fokus här har förändringarna för befolkningen i stort på arbetsmarknaden varit positiva men ganska små sedan millennieskiftet medan klara förbättringar har kunnat noteras för den ekonomiska situationen och vissa försämringar har skett av hälsoläget. Andelen sysselsatta har ökat något under perioden 1998/1999-2004/2005 medan andelen arbetslösa och i tidsbegränsad anställning har minskat något (detta gäller framförallt kvinnor). Fler har fått tillgång till en ekonomisk buffert, färre har haft problem att klara de löpande utgifterna under det senaste året och arbetsinkomster liksom disponibla inkomster har ökat kraf- tigt. Vad gäller hälsan så uppger fler att de lider av långvarig sjukdom och färre menar att deras allmänna hälsotillstånd är åtminstone gott. Hur relaterar denna utveckling till de tre grupper, de unga, de utrikesfödda och de ensamstående mödrarna, som utgör vårt huvudintresse här?

För ungdomarna är det allmänna mönstret att ganska lite har hänt under det nya millenniets första år. Andelen sysselsatta ungdomar har under senare år permanentats på en relativt låg nivå, runt 65 procent. Var tredje saknade således förvärvsarbete åren 2004/2005. Även om en stor andel av dessa studerade så kan knappt tio procent definieras som arbetslösa, en andel som är i det närmaste oförändrad över tid. Dessutom har var tredje av de unga anställda en tidsbegränsad anställning. Förvärvsarbetande ungdomar har alltså fortfarande svårt att få ordentligt fäste på arbetsmarknaden. Även om våra direkta indikatorer på ekonomiska svårigheter visar på en förbättring för gruppen så är inkomstutvecklingen påtagligt sämre än för befolkningen i stort, framförallt för unga män. Hälsoläget har förändrats mycket lite för unga vuxna vilket innebär att en relativt stor andel av 20-29-åringarna i vårt land, trots sin ringa ålder, uppger att de lider av ängslan, oro eller ångest.

För de utrikesfödda har förändringarna varit mer påtagliga. Den arbetskraftsreserv som gruppen har utgjort, och fortfarande utgör, har i ökande grad kommit att tas i anspråk av arbetsmarknaden under senare år. Andelen sysselsatta har ökat något, framförallt bland kvinnor födda utanför OECDområdet. Denna utveckling avspeglar sig också i att de utrikesfödda förbättrat sin 
ekonomiska situation. Medan förbättringen i tillgång till kontantmarginal och minskningen i ekonomiska svårigheter är i paritet med befolkningen i övrigt eller bättre så har de utrikesfödda dock fortsatt att halka efter i inkomst, såväl absolut som relativt. Hälsoutvecklingen bland de utrikesfödda påminner i stort om den som gäller för befolkningen i övrigt.

Mest splittrad förefaller utvecklingen för de ensamstående mödrarna vara. Andelen sysselsatta är oförändrad och fortfarande klart lägre än för sammanboende mödrar. Drygt vart fjärde hushåll med en ensamstående mor som familjeförsörjare måste för sin försörjning därför fortfarande till fullo förlita sig på andra inkomstkällor än förvärvsarbete. Trots detta har anknytningen till arbetsmarknaden förbättrats påtagligt. En minskande andel är arbetslös och i tidsbegränsad anställning. Den minskade arbetslösheten åtföljs dock av en motsvarande ökning i andelen förtidspensionärer i gruppen. Klart fler har också skaffat sig en ekonomisk buffert medan färre haft svårigheter att klara de löpande utgifterna under det senaste året. Paradoxalt nog har dock de ensamstående mödrarna fortsatt att tappa i inkomst gentemot den övriga befolkningen. Även om den disponibla inkomsten har ökat så har den ökat klart mindre än för befolkningen, både relativt och absolut. Hälsoutvecklingen har också varit klart mindre gynnsam för de ensamstående mödrarna än för andra grupper, med exempelvis påtagligt fler som uppger att deras hälsa inte är god.

Sammantaget är det alltså en inte alldeles entydig bild som vi kunnat teckna av hur välfärden för 1990-talets förlorargrupper har utvecklats under 2000-talets inledningsår. En anledning till detta är den tydliga polarisering av välfärdens fördelning inom dessa grupper som vår sambandsanalys visade. För alla grupperna finner vi att andelarna utan något välfärdsproblem (såsom vi här definierat dessa) har ökat, men samtidigt tycks andelarna med flera samtidiga välfärdsproblem ha varit antingen konstant eller till och med ha ökat något. Även om vi i en översiktsartikel av detta slag inte haft möjlighet att fördjupa oss i analyser för att förklara enskilda resultat eller vad som ligger bakom dessa polariseringstendenser, har vi förhoppningsvis tydligt nog visat att trots att 2000-talet så här långt präglats av allmänt goda tider är det en hel del som talar för att ofärden består eller till och med ökar för vissa befolkningsgrupper. 


\section{Referenser}

Appelqvist, M. (2000) „Flyktingmottagandet och den svenska välfärdsstaten under 1990-talet». I J. Frizell (red.) Välfärdens förutsättningar. SOU 2000 :37. Stockholm: Fritzes.

Atkinson T., Cantillon B., Marlier E. \& Nolan B. (2002) Social Indicators. The EU and Social Inclusion. Oxford: Oxford University Press.

Börjeson, M. (2001) "Vad innebar 1990-talet för ungdomars livsvillkor?». I A. Bergmark (red.) Ofärd i välfärden. SOU 2001:54. Stockholm: Fritzes.

Edin, P-A. \& Åslund, O. (2001) "Invandrare på 1990-talets arbetsmarknad». I Å. Bergmark (red.) Ofärd i välfärden. SOU 2001:54. Stockholm: Fritzes.

Erikson, R. \& Tåhlin, M. (1984) „Samgång mellan välfärdsproblem». I R. Erikson \& R. Åberg (red.) Välfärd i förändring. Stockholm: Prisma.

Fritzell, J. \& Lennartsson, C. (2005) „Financial transfers between generations in Sweden". Ageing and Society25, pp. 397-414.

Fritzell J., Lennartsson C. \& Lundberg O. (2007) "Health and inequalities in Sweden: long and short-term perspectives». I J. Fritzell \& O. Lundberg (red.) Health Inequalities and Welfare Resources: Continuity and Change in Sweden. Bristol: Policy Press.

Fritzell, J. \& Lundberg, O. (2000) Välfärd, ofärd och ojämlikhet. SOU 2000:41. Stockholm: Fritzes.

Fritzell, J. \& Lundberg, O. (2005) »Fighting inequalities in health and income - One important road to welfare and social development». I O. Kangas \& J. Palme (red.) Social Policy and Economic Development in the Nordic Countries. Basingstoke: Palgrave.

Fritzell, S. \& Burström, B. (2006) „Economic strain and self-rated health among lone and couple mothers in Sweden during the 1990s compared to the 1980s". Health Policy 79, pp. 253-264.

Fritzell S., Ringbäck Weitoft G., Fritzell J. \& Burström B. (kommande) "From macro to micro: The health of Swedish lone mothers during changing economic and social circumstances". Social Science \& Medicine.

Försäkringskassan (2006) Socialförsäkringsboken
2006. Stockholm: Försäkringskassan.

le Grand, C. \& Szulkin, R. (2002) „Permanent Disadvantage or Gradual Integration: Explaining the Immigrant-Native Earnings Gap in Sweden". Labour 16, pp. 37-64.

Gähler, M. (2001) „Bara en mor - ensamstående mödrars ekonomiska levnadsvillkor i 1990talets Sverige». I Å. Bergmark (red.) Ofärd $i$ välfärden. SOU 2001:54. Stockholm: Fritzes.

Gähler, M. (2006) "'To divorce is to die a bit...: A longitudinal study of marital disruption and psychological distress among Swedish women and men«. The Family Journal 14, pp. 372-382.

Hjern, A. \& Angel, B. (2000) "Organized violence and mental health of refugee children in exile: a six-year follow-up». Acta Paediatrica 89, pp. 722-727.

Hobson, B. \& Takahashi, M. (1997) "The ParentWorker Model: Lone Mothers in Sweden«. I J. Lewis (red.) Lone Mothers in European Welfare Regimes. Shifting Policy Logics. London: Jessica Kingsley Publishers.

Integrationsverket (2004) Rapport Integration 2003. Norrköping: Integrationsverket.

Kungliga Socialstyrelsen (1957) Ensamstående mödrars sociala och ekonomiska förhaillanden år 1955. Sveriges officiella statistik. Socialvård. Stockholm: Kungliga Socialstyrelsen.

Ringbäck Weitoft G., Haglund B., Hjern A. \& Rosén M. (2002) »Mortality, severe morbidity and injury among long-term lone mothers in Sweden". International Journal of Epidemiology 31, pp. 573-580.

Ringbäck Weitoft G., Haglund B. \& Rosén M. (2000) "Mortality among lone mothers in Sweden: a population study». Lancet 355, pp. 1215-1219.

SCB (2006a) Beskrivning av Sveriges befolkning. Stockholm: Statistiska centralbyrån.

SCB (2006b) Nationalräkenskaper 2000-2005. Sveriges officiella statistik. Statistiska meddelanden. NR 10SM 0601. Stockholm: Statistiska centralbyrån.

SCB (2006c) Inkomstfördelningsundersökningen 2004. Redovisning på riksnivå. Sveriges offi- 
ciella statistik. Statistiska meddelanden. HE 21

SM 0601. Stockholm: Statistiska centralbyrån.

SCB (2007) Arbetskraftsundersökningarna 2006.

Sveriges officiella statistik. Statistiska meddelanden. AM 12 SM 0701. Stockholm: Statistiska centralbyrån.

Sen, A. (1987) The Standard of Living. The Tanner

Lectures. Cambridge: Cambridge University Press.

Socialstyrelsen (2005) Folkhälsorapport 2005.

Stockholm: Socialstyrelsen.

SOU (2001:79) Välfärdsbokslut för 1990-talet.

Slutbetänkande Kommittén Välfärdsbokslut.
Stockholm: Fritzes.

SOU (2006:77) Ungdomar, stress och psykisk ohälsa. Stockholm: Fritzes.

Sørensen, A. (1994) „Women's economic risk and the economic position of single mothers". European Sociological Review 10, pp. 173-188.

Walzer, M. (1983) Spheres of Justice. A Defense of Pluralism and Equality. Oxford: Blackwell.

Åberg, R. \& Nordenmark, M. (2000) »Arbetslöshet och levnadsvillkor under 1990-talets krisåru. I J. Fritzell (red.) Välfärdens förutsättningar. SOU 2000:37. Stockholm: Fritzes.

\section{Appendix: data och variabler}

\section{Datamaterial}

Det datamaterial som använts här är SCB:s Undersökningar av levnadsförhållanden (ULF) för åren 1998/1999 och 2004/2005 om inte annat anges.

\section{Variabler och operationaliseringar}

Unga är individer i åldern 20-29 år. Notera att dessa fortfarande kan bo i uppväxthemmet, dvs. med en eller båda sina föräldrar.

Utrikesfödda 1 är personer födda i Västeuropa, USA, Kanada eller Australien.

Utrikesfödda 2 är personer födda i Afrika, Asien, det forna Östeuropa, Turkiet eller Sydamerika.

Ensamstående mor är de kvinnor som lever med minst ett barn under 18 år i hushållet men utan make, registrerad partner eller sambo. Barnet bor hos modern minst halva tiden.

Sysselsatta är de som uppgivit att de var anställda (hel- eller deltid), egna företagare eller jordbrukare veckan före intervjun.

I tidsbegränsad anställning är de anställda som inte är tillsvidareanställda.

Arbetslösa är de som uppgivit att de var arbetssökande och inte sysselsatta.

Arbetslösa >6 månader är de som varit arbetslösa enligt ovan i minst sex månader.

Förtidspensionär är de som inte är sysselsatta och uppbär sjukersättning eller aktivitetsersättning för unga. Dessa stödformer har ersatt förtidspension och ges till dem som har varaktigt eller tidsbegränsat nedsatt arbetsförmåga på grund av sjukdom eller annan nedsättning av den fysiska eller psykiska prestationsförmågan.

Arbetsinkomst utgörs av bruttolön, Ainkomst av jordbruksfastighet och

Fritzell, Gähler \& Nermo: Vad hände med 1990-talets stora förlorargrupper? Välfärd och ... 
rörelse och sjöinkomst samt sjuk- och föräldrapenning.

Disponibel inkomst är den summa pengar som återstår för konsumtion och sparande sedan man från förvärvs- och kapitalinkomster dragit slutlig skatt och lagt till skattefria ersättningar och bidrag (t.ex. socialbidrag, bostadsbidrag och barnbidrag). Här används ekvivalerad disponibel inkomst vilket innebär att den disponibla hushållsinkomsten har justerats med en så kallad ekvivalensskala för att ta hänsyn till hushållets storlek och sammansättning. På så sätt blir den disponibla inkomsten mer jämförbar mellan individer i olika hushållstyper. Enligt den ekvivalensskala som används här, som har utarbetats av SCB i samarbete med Kommittén Välfärdsbokslut tilldelas den första vuxna personen i hushållet vikten 1. Övriga vuxna personer tilldelas vikten 0,55 och barn under 18 år tilldelas vikten 0,47 . Den disponibla hushållsinkomsten divideras med summan av dessa vikter.

Saknar kontantmarginal gör de som saknar möjlighet (inklusive lån) att få fram en viss summa pengar i händelse av oförutsedda utgifter. Åren 1998/1999 var denna summa satt till 14000 kronor och 2004/2005 var den 15000 kronor.

Svårigheter att klara löpande utgifter har de som under de senaste 12 månaderna någon gång haft svårigheter med att klara de löpande utgifterna för mat, hyra, räkningar m.m.

Självskattad ohälsa lider de av som uppgivit att deras allmänna hälsotillstånd är sämre än gott på en fråga med fem svarsalternativ (mycket gott, gott, någorlunda, dåligt och mycket dåligt).

Ängslan, oro, ångest lider de av som uppgivit att de har lätta eller svåra besvär av ängslan, oro eller ångest.

Långvarig sjukdom lider de av som uppgivit att de har åtminstone en »långvarig sjukdom, besvär efter olycksfall, något handikapp eller annan svaghet (1998/1999) respektive »kroniska eller långvariga sjukdomar eller besvärı (2004/2005). Frågorna skiljer sig alltså något åt mellan de två undersökningsåren.

Långvarig sjukdom, svåra besvär lider de av som uppgivit att de har svåra eller mycket svåra besvär till följd av åtminstone en långvarig sjukdom (så som det definieras de båda undersökningsåren). 


\section{Summary}

\section{What happened to the disadvantaged groups of the 1990s?}

\section{Welfare and disadvantage during the first years of the new millennium}

The Swedish welfare commission singled out three social groups that were particularly hit by the severe economic recession in Sweden during the 1990s: young people, immigrants and single mothers. The purpose of this article is to study welfare changes within these three groups between 1998/1999 and 2004/2005, a period characterized by relatively good economic circumstances. The overall research question raised is: Have living conditions among these three groups become more similar to those of the population at large or have they continued to lag behind?

We focus on three central dimensions of welfare: work and employment, economic resources and health. Our results indicate a mixed welfare development for the groups in general, as in some respects for the population at large. Employment has increased somewhat, median income has increased substantially both at population level and within most of our groups. As for health, we find no betterment and in some groups and according to some indicators even a worsening. In particular we can note that the proportion with less than good self-rated health has increased among single mothers. What is perhaps most striking with regard to the findings is a polarization tendency within these three social categories. Whereas a larger share of immigrants and single mothers simultaneously report that they have employment, good self-rated health and a cash margin, we find no corresponding decrease in the proportions reporting troublesome living conditions according to all these three welfare dimensions; in fact among single mothers this latter fraction doubled in 2004/2005 compared to the end of the 1990s. 